\title{
POPULARNOŚĆ UNIEJOWA NA TLE MALYCH MIAST REGIONU LÓDZKIEGO ORAZ KONKURUJĄCYCH Z NIM UZDROWISK
}

\begin{abstract}
Zarys treści: Artykuł przedstawia przegląd popularności Uniejowa na tle małych miast województwa łódzkiego oraz uzdrowisk o podobnym kierunku leczniczym. Zjawisko to mierzono liczbą wyszukiwań w wyszukiwarce internetowej Google. Poza wspomnianym wyżej przeglądem poddano analizie sezonowe zmiany odnajdywania Uniejowa w Internecie i zestawiono je z działaniami promocyjnymi prowadzonymi przez Urząd Miasta. Wyniki wskazują, iż Uniejów jest najbardziej znaną jednostką w gronie małych miast regionu łódzkiego oraz znaczącą, jak na długość funkcjonowania uzdrowiska i jego potencjał, miejscowością uzdrowiskową.
\end{abstract}

Słowa kluczowe: Google trends, uzdrowisko, Uniejów

\section{WSTĘP}

Jedną z ról samorządów jest wspomaganie i nadzorowanie inwestycji w dziedzinie turystyki, w tym m.in.: przygotowywanie terenów pod inwestycje turystyczne, budowa infrastruktury obsługującej lokalne atrakcje czy proponowanie konkurencyjnych warunków inwestowania w tym sektorze ${ }^{1}$. Poza wymienionymi

* Paulina Kurzyk, mgr, asystent, Uniwersytet Łódzki, Wydział Nauk Geograficznych, Instytut Zagospodarowania Środowiska i Polityki Przestrzennej, 90-142 Łódź, ul. Kopcińskiego 31, e-mail: paulina.kurzyk@geo.uni.lodz.pl.

** Michał Kowalski, mgr, asystent, Uniwersytet Łódzki, Wydział Nauk Geograficznych, Instytut Zagospodarowania Środowiska i Polityki Przestrzennej, 90-142 Łódź, ul. Kopcińskiego 31, e-mail: michal.kowalski@geo.uni.lodz.pl.

1 T. Napierała, M. Adamiak, M. Lawin, Budżet samorzadowy jako narzędzie stymulacji rozwoju turystyki w gminach wiejskich województwa tódzkiego, „Studia Obszarów Wiejskich” 2013, nr 34, s. 247-260. 
wyżej kierunkami zadań samorząáw, zwłaszcza tych, które rozwój gospodarczy opierają na sferze krajobrazowej, niezwykle istotnym jest budowanie właściwego przekazu i wykorzystywanie w tym celu odpowiednio dobranych kanałów komunikacji. W związku z powyższym, władze wykorzystują liczne narzędzia marketingowe, będące formą wspierania konkurencyjności opartej na budowaniu wizerunku gminy i marki miejsca. Wspomniane narzędzia są elementami zarządzania marketingowego, które powinno przybierać charakter spójny, strategiczny i kompleksowy ${ }^{2}$. W efekcie miasta zaczynają się promować w sposób świadomy i celowy oraz oparty o swoje szeroko rozumiane zasoby, wykorzystując przy tym przekonywującą argumentację ich wyższości nad konkurencją. Ta forma wielokierunkowej, lecz spójnej działalności zmierza do poznania miasta i jego oferty, zainteresowania się nim i w konsekwencji wzbudzenia potrzeby przyjazdu do niego w celu skorzystania z usług w nim oferowanych. Ważnym przy tym jest, aby przekaz oddziaływał w dłuższym okresie niż trwa kampania. Odpowiednio przygotowana promocja miasta może decydować o sposobie postrzegania składników jego tożsamości, a w rezultacie o rodzaju ukształtowanego obrazu mentalnego - wizerunku marketingowego miasta ${ }^{3}$. A. Szromik dokonał przeglądu tendencji zmian podejść marketingowych stosowanych przez zarządców miast, wskazując na zmiany związane z zakresem promocji, jej formą, środkami i technikami komunikacyjnymi oraz metodami i podejściami operacyjnymi ${ }^{4}$. Promocja miasta, niezależnie od sposobu jej prowadzenia powinna przynosić wymierne efekty w postaci m.in. większej liczby turystów korzystających z lokalnej oferty. Niemniej ciekawym $\mathrm{i}$ istotnym, z punktu widzenia kreowania atrakcyjnego wizerunku miasta, wskaźnikiem obrazującym skuteczność promocji miasta jest jego popularność - w tym ta wirtualna (internetowa). Z pewną dozą ostrożności należy przyjąć, że liczba wyszukiwań informacji o danym mieście może przerodzić się w jego popularność i rozpoznawalność, a zakładając, iż ich wyniki będą przedstawiać pozytywne informacje - w utrwalenie pożądanego przez miasto wizerunku.

Współcześnie, rzeczywistość towarzysząca ludziom na co dzień oparta jest na systemie przyswajalnych informacji, które docierają do nich z różnych źródeł i z różną częstotliwością. Informacje marketingowe (szczególnie w zakresie promocji miasta), z racji ich charakteru i formy, stanowią impuls dla odbiorcy, który chcąc dowiedzieć się więcej na temat miasta (jego lokalizacji i dostępności, szerszego opisu oferty etc.) korzysta z dostępnych mu źródeł, poszerzających

2 M. Florek, A. Augustyn, Strategia promocji jednostek samorzadu terytorialnego - zasady i procedury, Europejski Instytut Marketingu Miejsc, Fundacja Bestplace, Warszawa 2011, s. 11.

3 A. Choliński, Product placement: planowanie, kreacja i pomiar skuteczności, Wyd. Wolters Kluwer, Warszawa 2013.

4 A. Szromnik, City placement - nowy element w strategii zintegrowanej komunikacji marketingowej miast, [w:] Marketing terytorialny, nowe obszary i narzędzia, red. A. Szromnik, Wyd. edu-Libri, Kraków-Legionowo 2015, s. 101. 
syntetycznie przestawioną ofertę. Niewątpliwie jednym z ważniejszych narzędzi, które mogą umożliwić wyszukiwanie informacji, wykorzystywanych na co dzień są przez człowieka jest wyszukiwarka internetowa, a więc system wyszukiwania informacji, umożliwiający znalezienie rozproszonych tekstów cyfrowych na podstawie słów kluczowych" 5 . Dominującą pozycję wśród tych systemów (zarówno w wymiarze polskim jak i globalnym) zajmuje wyszukiwarka Google ${ }^{6}$. Wagę źródeł internetowych wydają się potwierdzać badania przeprowadzone w Inowrocławiu i Ciechocinku, z których wynika, iż 45\% kuracjuszy, informacji o uzdrowiskach, wyszukuje w serwisach $\mathrm{WWW}^{7}$.

Wspomniana przez nas wcześniej popularność w Internecie może mieć kilka obliczy. Najpowszechniej mierzonymi są liczba trafień frazy w wyszukiwarce oraz jej wyszukiwalność. W przedłożonej pracy skupiono się na wyszukiwalności, przyjmując, że jest ona miernikiem popularności nie tyle związanej z tworzeniem wpisów na temat miasta, a miernikiem częstotliwości zapytań o miasto, wysyłanych przez internautów.

Wyszukiwalność sama w sobie, nie została dotąd jasno sprecyzowana w literaturze. Wśród pozycji, które w jakikolwiek sposób zwracają uwagę na to pojęcie wskazuje się opracowania z zakresu szeroko rozumianego IT ${ }^{8}$ traktującego ją jako składową rozwoju infrastruktury informacyjnej. Według przytoczonego opracowania wyszukiwalność ma być jednym z elementów, które wspierane przez sztukę i naukę kształtowania produktów informacyjnych, składają się na szeroką definicję architektury informacyjnej. Takie samo podejście reprezentowane jest w polskiej literaturze ${ }^{9}$. Boyd twierdzi, iż wyszukiwalność przekłada się na łatwość w odnajdowaniu przez użytkownika interesujących go materiałów ${ }^{10}$. W kontekście rozważań nad wyszukiwalnością warto przytoczyć definicję słownikową, według której coś wyszukiwalnego to coś co może zostać odszukane. W tym samym słowniku zauważono także, iż pojęciem tożsamym, choć nie używanym

5 A.Halavais, Wyszukiwarki internetowe a społeczeństwo, Wyd. Naukowe PWN, Warszawa 2012, s. 20.

6 M. Boguś, Proces ksztaltowania się korporacji ponadnarodowej Google, „Przedsiębiorczość - Edukacja” 2011, s. 141; K. Janc, Geografia internetu, Instytut Geografii i Rozwoju Regionalnego Uniwersytetu Wrocławskiego, Wrocław 2017, s. 109-110.

7 E. Koreleska, G. Stefański, Źródła informacji oraz ushugi uzdrowiskowe $w$ opinii kuracjuszy Ciechocinka i Inowrocaławia, „Studia i Materialy Polskiego Stowarzyszenia Zarządzania Wiedzą" 2013, nr 66, s. 51-61.

8 L. Rosenfeld, P. Morville, J. Arango, Information Architecture for the World Wide Web, Wyd. O’Reilly, Nowy Jork 2015.

9 S. Skórka, Nowe wyzwania architekruty informacji, „Bibliotheca Nostra. Ślaski Kwartalnik Naukowy" 2016, nr 2(44), s. 10-22.

${ }^{10}$ D. Boyd, Why Youth Heart Social Network Sites: The Role of Networked Publics in Teenage Social Life, [w:] Youth, Identity, and Digital Media, red. D. Buckingham, MIT Press, Cambridge 2008, s. 119-142. 
w nomenklaturze naukowej, jest pojęcie „googlowania”, które potocznie oznacza szukanie informacji w Internecie za pomocą wyszukiwarki Google ${ }^{11}$.

Wydaje się zatem, że, w kontekście przeprowadzonej analizy, wyszukiwalność to cecha, która towarzyszy miastu Uniejów, świadcząc o jego popularności wśród użytkowników Internetu, zainteresowanych zarówno tym miejscem w kontekście całego organizmu, jakim jest małe miasto, jak i jego funkcją uzdrowiskową.

Głównym celem artykułu jest ocena popularności Uniejowa na tle podobnych mu wielkością miast $\mathrm{w}$ regionie oraz na tle konkurencyjnych dla niego miejscowości uzdrowiskowych. Podjęto się również oceny skuteczności działań promocyjnych prowadzonych przez władze lokalne. Dodatkowo w ramach dyskusji nad zmiennością popularności Uniejowa w czasie, przedstawiono możliwe powody wspomnianych fluktuacji, które mogą być punktem wyjścia do szerszych analiz wpływu działań marketingowych na popularność miasta.

\section{ŹRÓDŁA I METODY BADAŃ}

Podstawowym źródłem informacji wykorzystanych w naszej analizie popularności miast są dane pochodzące z usługi Google Trends. Serwis ten, to instrument pozwalający na generowanie i udostępnianie informacji do celów biznesowych i marketingowych. Bazuje on na zapytaniach, które użytkownicy wpisują do wyszukiwarki Google. Wspomniane dane znajdują zastosowanie w wielu dziedzinach nauki. Począwszy od podstawowych zastosowań dla których usługa została stworzona, a więc badań marketingowych ${ }^{12}$, przez analizy ekonomiczne (w tym związane z prognozowaniem) ${ }^{13}$, społeczne ${ }^{14}$, aż po medycynę (szczególnie epidemiologię) $)^{15}$.

${ }^{11} \mathrm{https} / / /$ sjp.pwn.pl/szukaj/googlowa\%C4\%87.html [dostęp: 15.01.2019]

${ }^{12} \mathrm{~K}$. Hauke, Funkcjonalność narzędzi Google w search engine marketingu, „Studia i Prace Wydziału Nauk Ekonomicznych i Zarządzania” 2015, t. 2, nr 39, s. 113-25.

${ }^{13}$ S. Vosen, T. Schmidt, Forecasting Private Consumption: Survey-Based Indicators vs. Google Trends, „Journal of Forecasting” 2011, nr 30, s. 565-578; H. Choi, H. Varian, Predicting the Present with Google Trends, „Economic Record” 2012, nr 88, s. 2-9; T. Preis, H.S. Moat, H.E. Stanley, Quantifying Trading Behavior in Financial Markets Using Google Trends, „Scientific reports" 2013, nr 3(1684), s. 1-6.

${ }^{14}$ N. Askitas, K.F. Zimmermann, The Internet as a Data Source for Advancement in Social Sciences, „International Journal of Manpower” 2015, nr 36, s. 2-12.

${ }_{15}$ A. Seifter i in., The utility of «Google Trends» for epidemiological research: Lyme disease as an example, „Geospatial Health” 2010, nr 4(2), s. 135-137; M. Furmankiewicz, P. Ziuziański, Internet jako źródło danych epidemiologicznych, [w:] Rola informatyki w naukach ekonomicznych $i$ społecznych. Innowacje i implikacje interdyscyplinarne 2, red. Z.E. Zieliński, WSH w Kielcach, Kielce, 2013, s. 371-380. 
Wspomniana baza informacji, z uwagi na nieupowszechnianie danych wrażliwych (w tym objętych tajemnica handlową), umożliwia ich przeglądanie w formie przetworzonej, stąd konieczność skrupulatnego opisu sposobu ich pobierania $\mathrm{i}$ interpretacji.

Popularność miasta mierzono częstotliwością zapytań o frazę składającą się jedynie z nazwy interesujących nas miast (np. „Uniejów”, „Szadek”, „SzczawnoZdrój” etc.) z automatycznie proponowanym przez serwis rozszerzeniem „miasto w Polsce". Podczas pobierania danych nie stosowano udostępnionych przez serwis filtrów (ograniczeń do kategorii). Usługa Google Trends umożliwia przekazywanie danych jedynie $w$ formie porównawczej z ograniczeniem do pięciu fraz. Wspomniana forma porównawcza polega na zaprezentowaniu danych względnych, gdzie najwyższa miesięczna liczba zapytań w określonym przedziale czasowym dla porównywanych fraz wynosi 100, wartość 50 oznacza jej dwukrotnie niższą popularność, natomiast 0 świadczy o braku popularności danego miejsca. W związku z tym, iż do wspomnianych porównań można dodać maksymalnie pięć fraz, przy pozyskiwaniu danych z porównań, dostępnych w tej usłudze jako obiekt referencyjny przyjęto ten, w którym w danym okresie nastąpiło najwięcej zapytań w ciągu jednego miesiąca.

W efekcie, na skutek systematycznego pobierania danych, z wykorzystaniem obiektu referencyjnego, utworzono tabele danych przedstawiające porównywane obiekty w ujęciu miesięcznym, z przyporządkowaną względną wartością popularności frazy w wyszukiwarce Google (przykład jednej z bazy danych przedstawia tab. 1). Rezultatem tego jest 7 osobnych zestawien - po jednym dla każdej z porównywanych kategorii (jedno dla małych miast województwa łódzkiego tj. miast do 5 tys. mieszkańców oraz sześć tabel dla uzdrowisk o profilu leczenia zgodnym z profilem Uzdrowiska Uniejów). W zakresie porównań dotyczących uzdrowisk wyłączono $\mathrm{z}$ badań te o charakterze wsi oraz duże miasta. Wspomniane ograniczenie wiąże się z tym, iż informacje dostarczane przez Google Trends są danymi o charakterze względnym a tym samym uniemożliwiają porównania pomiędzy obserwacjami o zbyt dużych różnicach, w zakresie natężenia mierzonego zjawiska.

Dane zgromadzone na potrzeby badań obejmują okres od stycznia 2010 roku (rok poprzedzający wydanie decyzji Ministra Zdrowia w sprawie możliwości prowadzenia lecznictwa uzdrowiskowego na obszarze gminy Uniejów oraz dwa lata przed wydaniem rozporządzenia Prezesa Rady Ministrów w sprawie możliwości prowadzenia lecznictwa uzdrowiskowego w Uniejowie ${ }^{16}$ ) do końca 2017 roku.

Po zakończeniu żmudnego etapu kolekcjonowania danych wejściowych, przystąpiono do ich analiz z wykorzystaniem graficznych form prezentacji danych oraz prostych operacji statystycznych. Opis mierzonego zjawiska, wykonany

${ }^{16}$ Rozporzadzenie Rady Ministrów z dnia 27 czerwca 2012 r. w sprawie nadania statusu uzdrowiska miastu Uniejów wraz z solectwami: Spycimierz, Spycimierz-Kolonia, Zieleń i Człopy, położonym na obszarze gminy Uniejów, Dz.U. 2012, poz. 782. 
przy pomocy wspomnianych metod, ma charakter przeglądowy. Ostatnim etapem analiz była próba wyjaśnienia fluktuacji w zakresie popularności Uniejowa na tle wydarzeń w nim organizowanych.

\section{PODMIOT BADAŃ}

Uniejów, to miasto położone na terenie województwa łódzkiego, w powiecie poddębickim, zamieszkałe przez niewiele ponad 3 tys. mieszkańców. Pod względem gospodarczym ośrodek ten wyraźnie wyróżnia się na tle pozostałych małych miast regionu łódzkiego, istotnym udziałem w jego strukturze gospodarczej przedsiębiorstw działających w sekcjach związanych z zakwaterowaniem i gastronomią oraz kulturą, rozrywką i rekreacją ${ }^{17}$. Jest to wynik wysiłku lokalnych władz, aby Uniejów stał się ważnym graczem na arenie turystycznej, a więc na rynku wymagającym, poza wysoką jakością oferowanych usług, także dobrze i sprawnie działającego marketingu miejskiego. W 2008 roku szerokim echem odbiło się uruchomienie zasilanych wodami solankowymi Term (w kolejnych latach rozbudowywanych) ${ }^{18}$. W oparciu o ten kompleks, oraz z uwagi na współwystępowanie dodatkowych czynników wzmacniających lokalny potencjał (m.in. bogatą historię geologiczną, która zapewnia mu szczególne walory mikroklimatyczne, historyczny kompleks edukacyjno-turystyczno-rekreacyjny, ukształtowane w społecznej świadomości festiwale i niematerialne dziedzictwo sąsiadującego nieopodal Spicymierza), podjęto decyzję związaną z realizacją koncepcji promocji Uniejowa w kierunku „,młodego duchem uzdrowiska", z dominującym profilem profilaktycznym, pełniącym funkcję „kapsuły zdrowia, młodości i witalności”" ${ }^{19}$. W efekcie w sierpniu $2011 \mathrm{r}$. Minister Zdrowia zatwierdziła możliwość prowadzenia lecznictwa uzdrowiskowego w Uniejowie, w kierunkach leczenia chorób: ortopedyczno-urazowych, układu nerwowego, reumatologicznych, naczyń obwodowych oraz skóry ${ }^{20}$, a w czerwcu 2012 r. miasto uzyskało status miejscowości uzdrowiskowej ${ }^{21}$.

${ }^{17}$ M. Kowalski, Pozarolnicza działalność gospodarcza w gminie Uniejów, „Biuletyn Uniejowski" 2015, t. 4, s. 143-156.

${ }^{18}$ E. Gorczyczewska, K. Smętkiewicz, Budowa i promocja marki miejsca na przykładzie uzdrowiska termalnego Uniejów, „Studia Ekonomiczne. Zeszyty Naukowe Uniwersytetu Ekonomicznego w Katowicach” 2013, nr 144, s. 395-408.

19 Tamże.

${ }^{20} \mathrm{~K}$. Smętkiewicz, T. Latour, Właściwości fizykochemiczne i chemiczne wód geotermalnych w Uniejowie ze szczególnym uwzględnieniem wody z odwiertu PIG/AGH-2, „Biuletyn Uniejowski” 2012, t. 1, s. 79-93.

${ }^{21}$ Rozporzadzenie Rady Ministrów z dnia 27 czerwca 2012 r. w sprawie nadania statusu uzdrowiska miastu Uniejów wraz z sołectwami: Spycimierz, Spycimierz-Kolonia, Zieleń i Człopy, położonym na obszarze gminy Uniejów, Dz.U. 2012, poz. 781. 
Budowa i promocja marki Uniejowa i uzdrowiska termalnego w nim usytuowanego w sposób kompleksowy scharakteryzowały E. Gorczyczewska i K. Smętkiewicz wskazując na techniki Public Relactions (PR), hasła promocyjne, kanały upowszechniania informacji o mieście oraz o markach z nim związanych ${ }^{22}$. W kontekście przywołanych analiz w Uniejowie wyraźnie uwidacznia się stosunkowo nowe podejście do marketingu nazywane w literaturze productplacement 'em ${ }^{23}$ (lokowaniem produktu), które A. Szromik w kontekście marketingu miejskiego nazywa cityplacement'em ${ }^{24}$.

\section{WYNIKI}

\section{Popularność Uniejowa na tle małych miast regionu lódzkiego}

W województwie łódzkim łącznie 44 jednostki posiadają status miasta, $\mathrm{z}$ czego 13 miast zamieszkuje mniej niż 5 tys. mieszkańców. W tej grupie ośrodków jednoznacznie daje się zaobserwować dominację Uniejowa nad pozostałymi miastami w zakresie popularności ustalonej na podstawie miernika wyszukiwalności (ryc. 1). Wynik uśrednionego pomiaru zjawiska nie ukazuje w pełni obrazu dominacji tego miasta wśród ośrodków o podobnym potencjale demograficznym. Lepszym narzędziem ukazującym różnice $\mathrm{w}$ popularności oraz istniejące trendy w tym zakresie jest wykres liniowy (ryc. 2). W tym przypadku z uwagi na jego przejrzystość ograniczono liczbę miast do tych, których najwyższa miesięczna obserwacja wynosiła więcej niż 10\% wartości obserwacji maksymalnej w całym okresie badania.

Przyczyn popularności omawianego miejsca, należy doszukiwać się, poza aktywnością w zakresie promocji jednostek terytorialnych, w tym, iż Uniejów jest jedynym $\mathrm{w}$ grupie małych miast miejscem, które w dużej mierze opiera swój rozwój na turystyce. W całym okresie objętym badaniem, jedynie Stryków i Rzgów, a więc miasta w których rozwijają się funkcje egzogeniczne, wynikające z położenia w złotym trójkącie logistycznym ${ }^{25}$ (i co za tym idzie ze zlokalizowanymi w nich centrami logistycznymi ${ }^{26} \mathrm{i}$ handlowymi ${ }^{27}$ ), zbliżyły się w niektórych

${ }^{22}$ Por. E. Gorczyczewska, K. Smętkiewicz.

${ }^{23}$ Por. P.B. Gupta., K.R. Lord; Por. C. La Farle i S.M. Edwards.

${ }^{24}$ Por. A. Szromnik.

${ }^{25}$ S. Wiśniewski, Significance of trans-european transport networks for logistics centre localization as exemplified by the Łódź region, „European Spatail Research and Policy” 2015, t. 22, nr 1, s. 23-44.

${ }^{26}$ B. Bartosiewicz, S. Wiśniewski, Przemiany małego miasta i jego otoczenia a rozwój centrów logistycznych - przykład miasta i gminy Strykowa, [w:] Przemiany przestrzeni i potencjatu matych miast $w$ wybranych regionach Polski z perspektywy 20 lat transformacji, red. B. Bartosiewicz, T. Marszał, Wyd. Uniwersytetu Łódzkiego, Łódź 2011, s. 93-118.

27 J. Dzieciuchowicz, Wielkie centrum handlowe w przestrzeni miejskiej i podmiejskiej: Manufaktura w Łodzi i Ptak w Rzgowie, Wyd. Uniwersytetu Łódzkiego, Łódź 2012. 
miesiącach do poziomu popularności Uniejowa (Rzgów w październiku 2010 r.) lub nieznacznie ją przewyższały (Stryków w październiku 2011 r.).

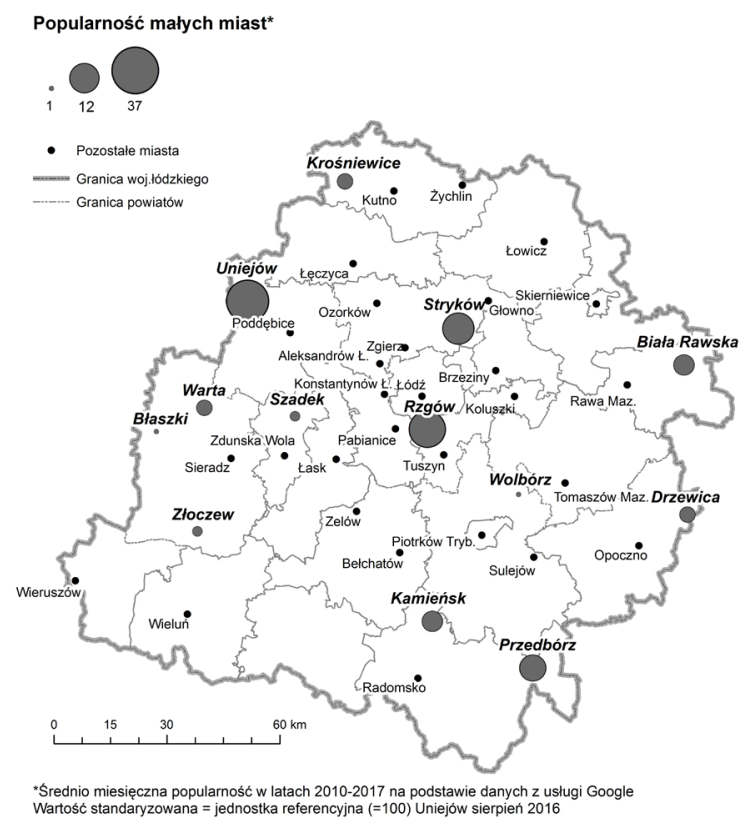

Ryc. 1. Popularność wyszukiwania w serwisie Google małych miast województwa łódzkiego Źródło: opracowanie własne

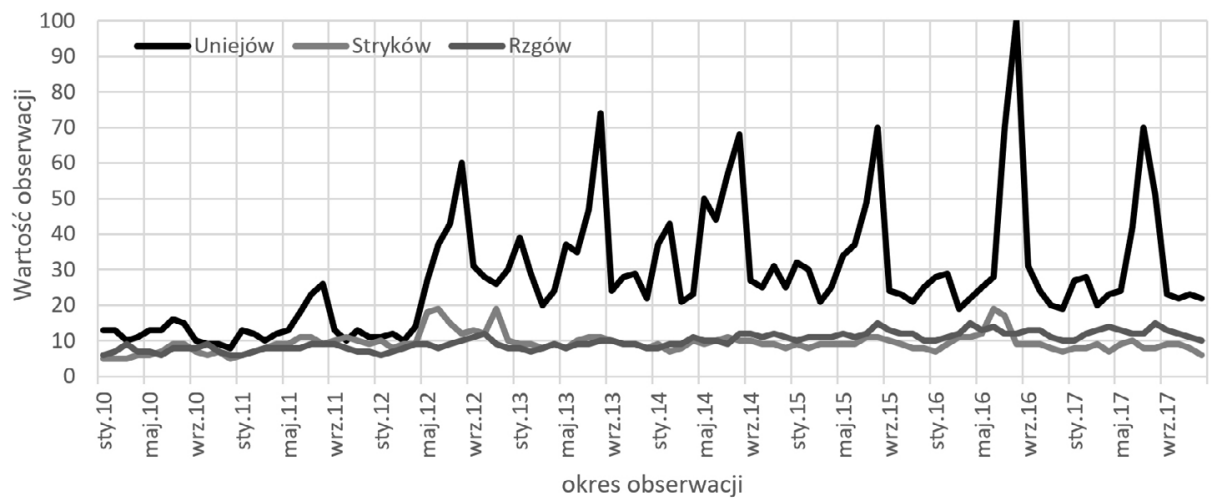

Ryc. 2. Częstotliwość wyszukiwań Uniejowa, Strykowa i Rzgowa w serwisie Google na podstawie miesięcznych miar $\mathrm{z}$ lat 2010-2017*

* Dane standaryzowane. Jednostka referencyjna $(=100)$ ustalona na podstawie najwyższej wartości pomiaru ze zbioru ogółu małych miast województwa łódzkiego (Uniejów - pomiar z sierpnia $2016=100$ )

Źródło: opracowanie własne 


\section{POPULARNOŚĆ UNIEJOWA NA TLE KONKURENCYJNYCH UZDROWISK}

Zgodnie z ustawą z dnia 28 lipca 2005 roku o lecznictwie uzdrowiskowym, uzdrowiskach i obszarach ochrony uzdrowiskowej oraz o gminach uzdrowiskowych (Dz.U. 2012, poz. 651), Uniejów jest miastem na obszarze którego prowadzone jest lecznictwo uzdrowiskowe, wydzielone w celu wykorzystania i ochrony znajdujących się na terenie naturalnych surowców leczniczych. Zgodnie z powyższym, posiadanie statusu uzdrowiska prowadzi do powstania podstawy prawno-organizacyjnej, która stanowi fundament do prowadzenia na danym obszarze lecznictwa uzdrowiskowego, a także działalności turystycznej oraz wypoczynkowej. Uzdrowiska klasyfikuje się według wielu różnych wyróżników, z czego na ogół systematyzuje się kurorty przyjmując za kryterium ich położenie geograficzne, kierunki lecznicze oraz występujące naturalne surowce lecznicze. W przedstawionych badaniach podjęto próbę oceny popularności uzdrowisk w oparciu o dwa pierwsze kryteria.

W zakresie podziału kurortów leczniczych z uwzględnieniem ich położenia geograficznego wyróżnia się uzdrowiska górskie, podgórskie, nizinne i nadmorskie. Uniejów w tej klasyfikacji znajduje się wśród 17 uzdrowisk nizinnych, czyli tych położonych do wysokości $200 \mathrm{~m}$ n.p.m. Dwanaście z nich to uzdrowiska zlokalizowane w miastach, z czego do analiz wybrano 11 jednostek ${ }^{28}$ (załącznik 1).

Uniejów we wspomnianej grupie nie znajduje się wśród miejsc najbardziej popularnych. Generalnie uśredniony wynik uzyskany przez badaną jednostkę kształtuje się na podobnym poziomie jak w Gołdapii, Konstancinie-Jeziornej, które status uzdrowiska uzyskały wcześniej aniżeli Uniejów (odpowiednio - 200029 i $1967^{30}$ roku) (ryc. 3). Patrząc jednak na zmienność badanego zjawiska w czasie należy zauważyć, iż w ostatnim czasie, zwłaszcza latem, popularność Uniejowa osiąga poziom zbliżony do wyników Buska-Zdroju i Ciechocinka, ulegając w tym okresie jedynie takim jednostkom jak Inowrocław i Augustów (a więc ośrodkom o zdecydowanie większym potencjale demograficznym, odpowiednio: ok. 73 tys. i 30 tys. mieszkańców).

${ }^{28} \mathrm{Z}$ uzdrowisk poddanych analizie wyłączono wsie i duże miasta (jednym z uzdrowisk nizinnych zlokalizowanych w dużym mieście jest uzdrowisko w Swoszowicach, a więc osiedlu wchodzącego w skład Krakowa).

${ }^{29}$ J. Górna, Miejska turystyka uzdrowiskowa i kierunki jej ewolucji w Polsce, „Studia Ekonomiczne. Zeszyty Naukowe Uniwersytetu Ekonomicznego w Katowicach" 2013, nr 147, s. 53-67.

${ }^{30} \mathrm{~K}$. Duda-Gromada, $W$ blasku czy cieniu metropolii? Rozwój podstolecznej miejscowosci na przykładzie Konstancina-Jeziorny, [w:] Przeszłość, teraźniejszość i przyszłość turystyki, „Warsztaty z Geografii Turyzmu”, t. 5, red. B. Krakowiak, J. Latosińska, Wyd. Uniwersytetu Łódzkiego, Łódź 2013, s. 145-159. 


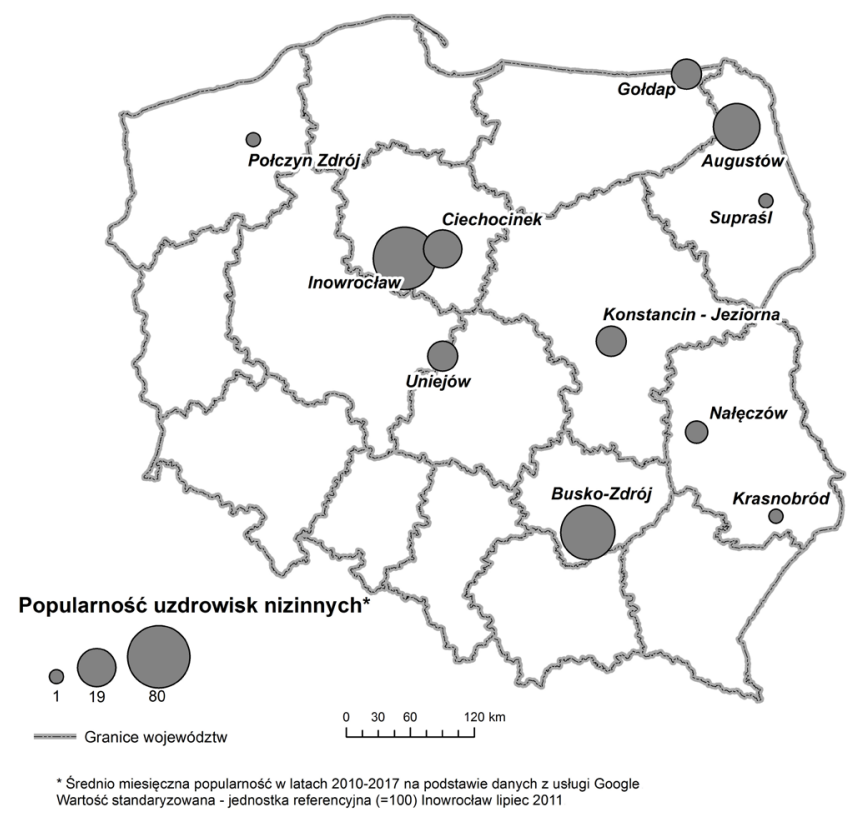

Ryc. 3. Popularność wyszukiwania w serwisie Google miast-uzdrowisk nizinnych Źródło: opracowanie własne

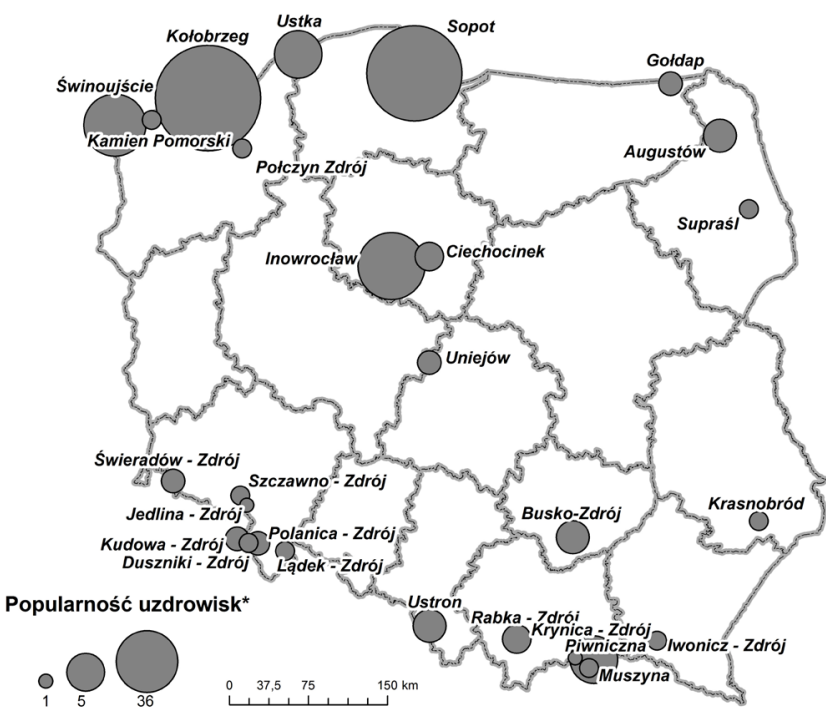

-.-.-.- Granice województw

* Średnio miesięczna popularność w latach 2010-2017 na podstawie danych z usługi Google

Ryc. 4. Popularność wyszukiwania w serwisie Google miast-uzdrowisk o kierunku leczenia chorób reumatycznych Źródło: opracowanie własne 
Wójtowie gmin, burmistrzowie i prezydenci miast uzdrowiskowych przedkładają Ministrowi Zdrowia operaty uzdrowiskowe (składające się m.in. świadectwa wód, borowin, klimatu wydane przez uprawnione jednostki naukowe). Na ich podstawie wydawane są decyzje o profilu uzdrowiska, a ściślej o możliwości prowadzenia lecznictwa uzdrowiskowego w określonych kierunkach leczniczych ${ }^{31}$. Zatem, istnieją grupy uzdrowisk o podobnych profilach leczniczych, w ramach których dochodzi do konkurowania. W tym kontekście Uniejów konkuruje z uzdrowiskami wspomagającymi leczenie chorób: układu nerwowego, ortopedyczno-urazowych, reumatologicznych, naczyń obwodowych i skóry.

Przegląd popularności Uniejowa na tle jego konkurencji, w grupach o poszczególnym profilu leczniczym, ilustrują ryciny 4, 5, 6, 7 i 8. Podczas badania, porównano wyniki w każdej z tych grup. Grupy różniły się wielkością, co wynikało z liczby miejscowości uzdrowiskowych o danym charakterze leczniczym. Wśród wskazanych grup leczniczych, najbardziej liczną są uzdrowiska, których charakter obejmuje leczenie chorób reumatologicznych (ryc. 4). Wśród nich hasło Uniejów jest stosunkowo mało popularne.

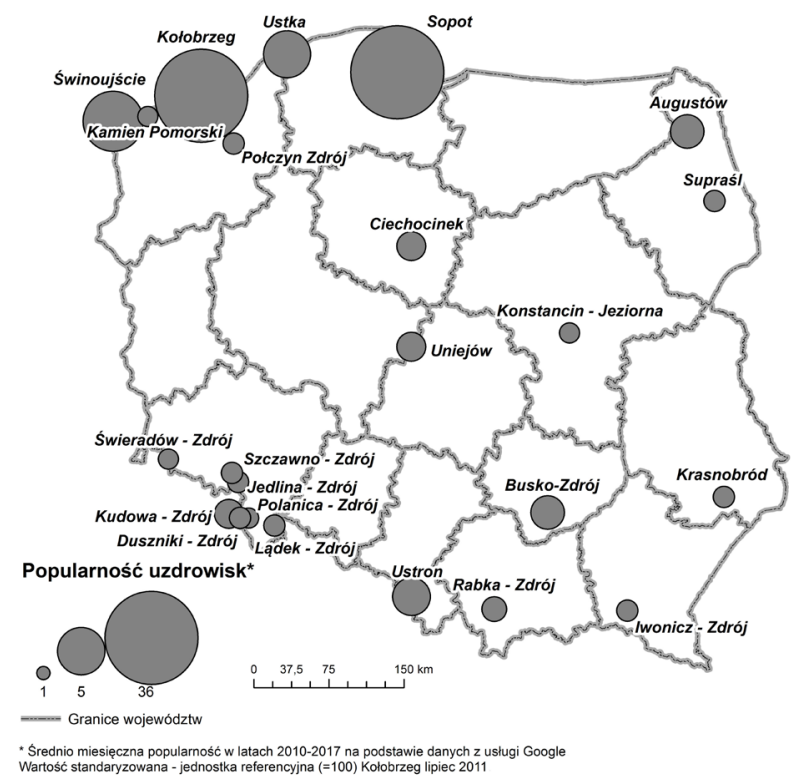

Ryc. 5. Popularność wyszukiwania w serwisie Google miast-uzdrowisk o kierunku leczenia chorób ortopedyczno-urazowych Źródło: opracowanie własne

${ }^{31}$ Ustawa z dnia 28 lipca 2005 r. o lecznictwie uzdrowiskowym, uzdrowiskach i obszarach ochrony uzdrowiskowej oraz o gminach uzdrowiskowych, Dz.U. 2017, poz. 1056. 
Kolejną grupą miast uzdrowisk, objętą analizą, są ośrodki przystosowane do lecznictwa chorób ortopedyczno-urazowych (ryc. 5). Wśród nich jednostką referencyjną jest Kołobrzeg, którego popularność jest największa. Popularność Uniejowa natomiast jest mniejsza i kształtuje się na podobnym poziomie jak Buska-Zdroju czy Ustronia.

Kolejne trzy grupy stanowiły zbiory mniej liczne. Pod względem liczebności, podobne okazały się grupy uzdrowisk, których profil leczniczy zakwalifikowano jako odpowiedni do leczenia chorób skóry (ryc. 6) oraz układu nerwowego (ryc. 7). W obydwu przypadkach, jednostkami referencyjnymi okazał się Kołobrzeg. Popularność Uniejowa w tych grupach jest zbliżona do obserwacji charakteryzujących takie uzdrowiska jak: Rabka Zdrój i Konstancin-Jeziorna.

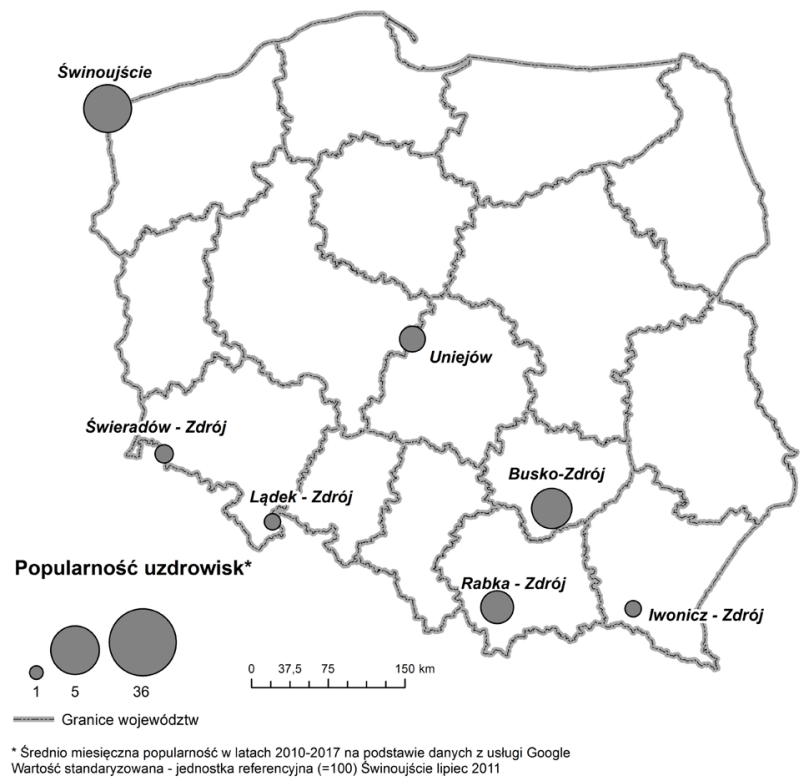

Ryc. 6. Popularność wyszukiwania w serwisie Google miast-uzdrowisk

o kierunku leczenia chorób skóry

Źródło: opracowanie własne

Ostatnią kategorią lecznictwa chorób w ramach uzdrowisk, do której zalicza się Uniejów, są choroby naczyń obwodowych (ryc. 8). Grupa składa się z ośmiu jednostek, gdzie wiodącą okazał się Inowrocław, natomiast popularność Uniejowa jest wyższa od takich kurortów jak: Świeradów Zdrój i Lądek Zdrój.

Wspomniane wyżej zestawiania wyraźnie wskazują, iż najwyższymi wskaźnikami popularności charakteryzują się miejscowości o wysokim potencjale turystycznym i demograficznym (szczególnie ośrodki nadmorskie). Dlatego też znaczna część ich popularności wynika z pozauzdrowiskowej działalności. 


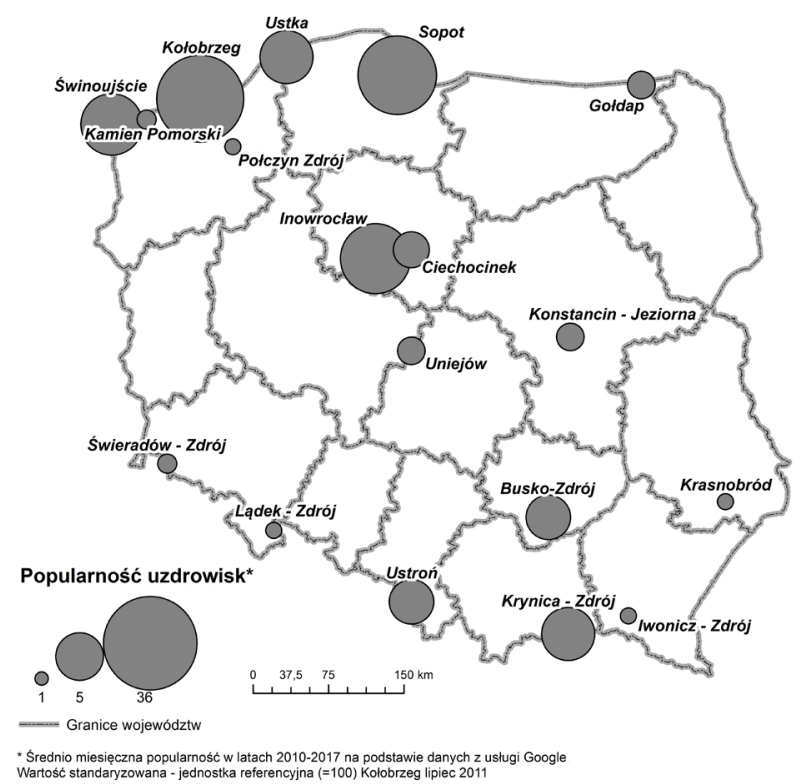

Ryc. 7. Popularność wyszukiwania w serwisie Google miast-uzdrowisk o kierunku leczenia chorób układu nerwowego Źródło: opracowanie własne

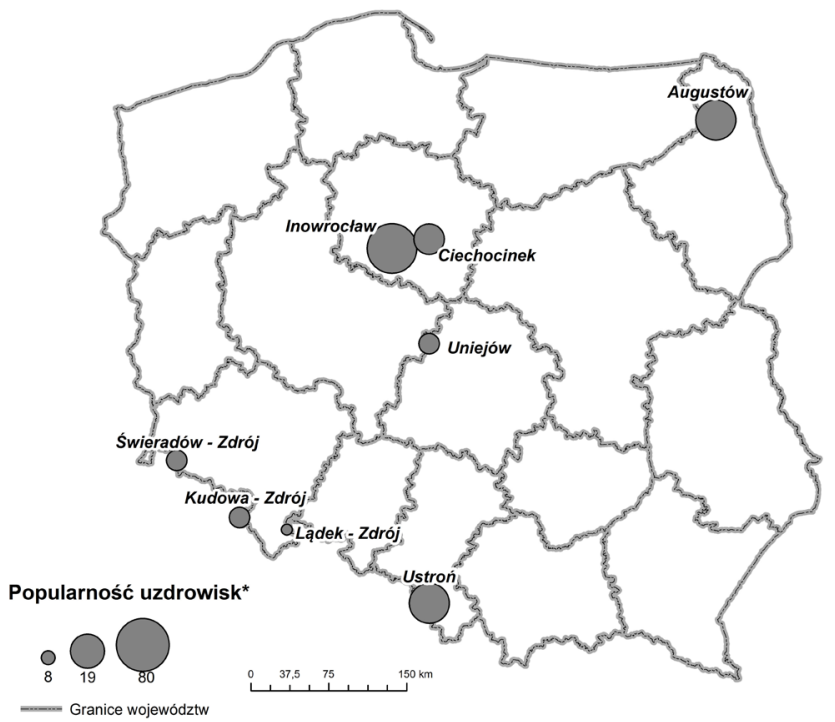

* Średnio miesięczna popularnosćc w latach 2010-2017 na podstawie danych z usługi Google Wartosć standaryzowana - jednostka referencyjna (=100) Kołobrzeg lipiec 2011

Ryc. 8. Popularność wyszukiwania w serwisie Google miast-uzdrowisk o kierunku leczenia chorób naczyń obwodowych Źródło: opracowanie własne 


\section{ZMIANY POPULARNOŚCI UNIEJOWA - PRÓBA WYJAŚNIENIA}

W wyniku przeprowadzonej analizy, stwierdziliśmy, iż właściwym będzie podjęcie się próby wyjaśniania zmian popularności Uniejowa (ryc. 2). Wpływ na wspomnianą zmienność mają przede wszystkim wydarzenia związane z promocją miasta. Pierwszy wyraźny wzrost popularności zaobserwowano w 2011 roku, wtedy też miasto otrzymało pozytywną opinię Ministra Zdrowia w sprawie prowadzenia lecznictwa uzdrowiskowego na jego terenie. Największe wzrosty Uniejowa w tym roku obserwowano w lipcu, a więc w miesiącu bogatym w wydarzenia medialne, takie jak m.in., organizowany cyklicznie, „Turniej Rycerski” czy „Indiańskie lato im. Sat-Okha”. 3 lipca 2011 roku to dzień, w którym popularność Uniejowa na przestrzeni całego tego roku była największa.

Od 2012 roku popularność Uniejowa utrzymuje się na wyższym, stałym (z kilkoma wzrostami) poziomie. Jest to pokłosie wydania rozporządzenia Prezesa Rady Ministrów w sprawie nadania miastu statusu uzdrowiska termalnego. Według K. Smętkiewicz i E. Goryczewskiej ${ }^{32}$ to właśnie czerwiec 2012 i wydanie wyżej wspomnianego rozporządzenia stanowi początek promocji miasta. Ponadto rok 2012 obfituje w wydarzenia, które wzmacniają promocję, a tym samym podnoszą popularność Uniejowa. Zaznaczyć należy m.in., iż w roku tym doszło do rozbudowania obiektu „Termy Uniejów” oraz kompleksu historycznego „Wrota Czasu”. Tym samym powiększono bazę turystyczną miasta o nowe atrakcje edukacyjno-rekreacyjne oraz noclegi. Strategia promocji miasta obejmuje również organizację eventów o charakterze masowym, przy współpracy z mediami ogólnopolskimi. Zgodnie z tym, w czerwcu 2012 roku w Uniejowie miał miejsce koncert z cyklu „Lato z Radiem” organizowany przy współpracy z Programem 1 Polskiego Radia. W sierpniu odbył się z kolei koncert organizowany przez TVP2 i Radio Zet pt. „Lato ZET i Dwójki”. Kolejnym wydarzeniem związanym z 2012 rokiem była czerwcowa wizyta studyjna członków Komitetu Regionów i Komisji Środowiska UE „Uniejów - wody termalne naturalnym bogactwem regionu”. W październiku Uniejów odwiedził ówczesny prezydent RP, Bronisław Komorowski. Analizując rozkład wyszukań hasła Uniejów dla tego okresu zauważono, iż szczyt popularności przypada na ostatni tydzień sierpnia i początek września, jednakże znaczącym wzrostem wykazuje się również początek października, co połączyć można z sierpniową imprezą masową oraz wizytą Prezydenta RP (ryc. 9).

Hasło „Uniejów” cieszy się największą popularnością w okresie letnim, od maja do września (ryc. 2), kiedy to organizowane są pozostałe eventy, które mają na celu budowanie marki miejsca, a tym samym podnoszenia jego popularności. W tym czasie odbywają się: „Dni Uniejowa” - impreza o charakterze kulturalno-rozrywkowym (przełom maja i czerwca), „Ogólnopolskie Dni Wody”

32 por. E. Goryczewska, K. Smętkiewicz. 


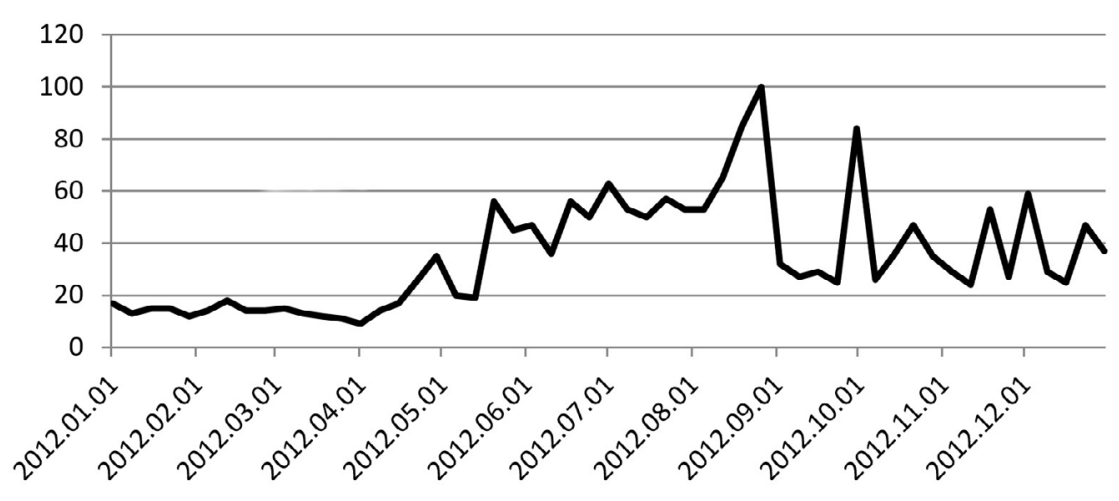

Ryc. 9. Wyszukiwalność hasła Uniejów w 2012 roku Źródło: opracowanie własne

(w czerwcu), Wielki Turniej Rycerski na zamku w Uniejowie oraz Indiańskie Lato im. Sat-Okha (w lipcu). Oczywistym faktem jest, że wskazany okres to sezon urlopowy, który związany jest z wyjazdami i aktywnym spędzaniem czasu, jednak uatrakcyjnienie oferty wydarzeniami cyklicznymi jak te zaprezentowane powyżej zdecydowanie wpływa na wzrost popularności miejsca. O słuszności cykliczności i powtarzaniu wydarzeń kulturalnych podczas procesu budowania marki miejsca mogą świadczyć wyniki osiągnięte w 2016 roku (ryc. 10), które ukazano w najbardziej bogatym w wydarzenia kulturalne okresie w ciągu roku. Wtedy też po raz kolejny zorganizowano koncert przy współpracy radia Zet oraz tym razem telewizji Polsat. 24 lipca 2016 roku osiągnięto najwyższy wynik wyszukiwań hasła Uniejów, który przypada na dzień wspomnianego koncertu, ponadto jest to szczytowy wynik w porównaniu z wszystkimi małymi miastami województwa łódzkiego.

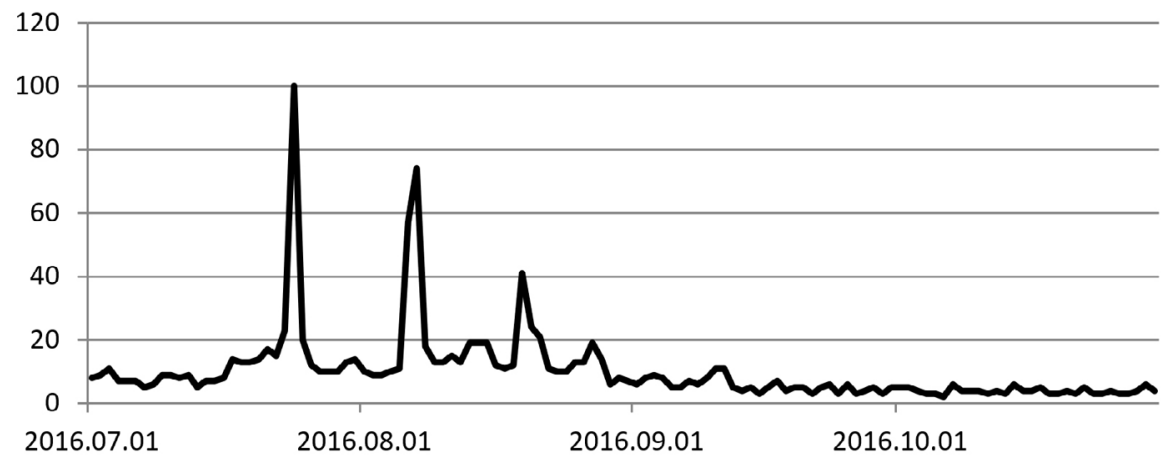

Ryc. 10. Wyszukiwalność hasła Uniejów w 2016 roku Źródło: opracowanie własne 


\section{WNIOSKI}

Dane pochodzące z usług przeglądarkowych, pomimo ich ułomności związanych m.in. ze sposobem ich agregacji umożliwiają stosunkowo dokładną analizę porównawczą (pomiędzy frazami). Mogą być również jednym ze wskaźników ewaluacji działań promocyjnych. Na ich podstawie ustalono, że Uniejów jest najbardziej popularnym małym miastem $\mathrm{w}$ regionie łódzkim. Popularność ta, wśród innych miast uzdrowisk jest stosunkowo duża, jeśli wziąć pod uwagę potencjał demograficzny ośrodka oraz brak innych istotnych atraktorów (położenie nadmorskie lub górskie).

Dotychczasowe działania promocyjne miasta znajdują swoje odzwierciedlenie w ruchu obserwowanym w Internecie. Szczególnie działania promocyjne związane z cityplacement (organizacja imprez i wydarzeń wespół z koncernami medialnymi) w sposób widoczny przyczynia się do zwiększonej wyszukiwalności Uniejowa (szczególnie w dniu wydarzenia).

\section{Bibliografia}

Askitasi N., Zimmermann K.F., The Internet as a Data Source for Advancement in Social Sciences”, „International Journal of Manpower” 2015, nr 36, s. 2-12.

Bartosiewicz B., Wiśniewski S., Przemiany matego miasta i jego otoczenia a rozwój centrów logistycznych - przyklad miasta i gminy Strykowa, [w:] Przemiany przestrzeni i potencjalu matych miast $w$ wybranych regionach Polski z perspektywy 20 lat transformacji, red. B. Bartosiewicz, T. Marszał, Wyd. Uniwersytetu Łódzkiego, Łódź 2011, s. 93-118.

Boguś M., Proces ksztattowania się korporacji ponadnarodowej Google, „Przedsiębiorczość - Edukacja”, 2011, s. 128-145.

Boyd D., Why Youth Heart Social Network Sites: The Role of Networked Publics in Teenage Social Life, [w:] Youth, Identity, and Digital Media, red. D. Buckingham, MIT Press, Cambridge 2008, s. 119-42.

Choi H., Varian H., Predicting the Present with Google Trends, „Economic Record” 2012, nr 88, s. 2-9.

Duda-Gromada K., W blasku czy cieniu metropolii? Rozwój podstołecznej miejscowosci na przykładzie Konstancina-Jeziorny, [w:] Przeszłość, teraźniejszość i przyszłość turystyki, „Warsztaty z Geografii Turyzmu”, t. 5, red. B. Krakowiak, J. Latosińska, Wyd. Uniwersytetu Łódzkiego, Łódź 2013, s. 145-159.

Dzieciuchowicz J., Wielkie centrum handlowe w przestrzeni miejskiej i podmiejskiej: Manufaktura w Łodzi i Ptak w Rzgowie, Wyd. Uniwersytetu Łódzkiego, Łódź 2012.

Florek M., Augustyn A., Strategia promocji jednostek samorzadu terytorialnego - zasady i procedury, Fundacja Bestplace, Europejski Instytut Marketingu Miejsc, Warszawa 2011, s. 11.

Furmankiewicz M., Ziuziański P. Internet jako źródto danych epidemiologicznych, [w:] Rola informatyki w naukach ekonomicznych i społecznych. Innowacje i implikacje interdyscyplinarne 2, red. Z.E. Zieliński, WSH w Kielcach, Kielce 2013, s. 371-380.

Gorczyczewska E., Smętkiewicz K., Budowa i promocja marki miejsca na przykładzie uzdrowiska termalnego Uniejów, „Studia Ekonomiczne. Zeszyty Naukowe Uniwersytetu Ekonomicznego w Katowicach" 2013, nr 144, s. 395-408. 
Górna J., Miejska turystyka uzdrowiskowa i kierunki jej ewolucji w Polsce, „Studia Ekonomiczne. Zeszyty Naukowe Uniwersytetu Ekonomicznego w Katowicach” 2013, nr 147, s. 53-67.

Gupta P.B., Lord K.R, Product Placement in Movies: The Effect of Prominence and Mode on Audience Recall Mode on Audience Recall, ,Journal of Current Issues \& Research in Advertising” 1998, nr 20(1), s. 47-59.

Halavais A., Wyszukiwarki internetowe a społeczeństwo, Wyd. Naukowe PWN, Warszawa 2012, s. 20.

Hauke K., Funkcjonalność narzędzi Google w searchengine marketingu, „Studia i Prace Wydziału Nauk Ekonomicznych i Zarządzania” 2015, t. 2, nr 39, s. 113-125.

https://sjp.pwn.pl/szukaj/googlowa\%C4\%87.html [dostęp: 15.01.2019]

Janc K., Geografia Internetu, Instytut Geografii i Rozwoju Regionalnego Uniwersytetu Wrocławskiego, Wrocław 2017, s. 109-110.

Koreleska E., Stefański G., Źródła informacji oraz usługi uzdrowiskowe w opinii kuracjuszy Ciechocinka i Inowrocaławia, „Studia i Materiały Polskiego Stowarzyszenia Zarzadzania Wiedzą" 2013, nr 66, s. 51-61.

Kowalski M., Pozarolnicza działalność gospodarcza w gminie Uniejów, „Biuletyn Uniejowski” 2015 , t. 4, s. $143-156$.

La Farlei C., Edwards S.M., Product Placement: How Brands Appear on Television, „Journal of Advertising" 2006, nr 35(4), s. 65-86.

Napierała T., Adamiak M., Lawin M., Budżet samorzadowy jako narzędzie stymulacji rozwoju turystyki w gminach wiejskich województwa tódzkiego, „Studia Obszarów Wiejskich” 2013, nr 34, s. 247-260.

Preis T., Moat H.S., Stanley H.E., Quantifying Trading Behavior in Financial Markets Using Google Trends, „Scientific reports” 2013, nr 3(1684), s. 1-6.

Rosenfeld L., Morville P., Arango J., Information Architecture for the World Wide Web, O'Reilly, Nowy Jork 2015.

Rozporzadzenie Rady Ministrów z dnia 27 czerwca 2012 r. w sprawie nadania statusu uzdrowiska miastu Uniejów wraz z sołectwami: Spycimierz, Spycimierz-Kolonia, Zieleń i Człopy położonym na obszarze gminy Uniejów, Dz.U. 2012, poz. 782.

Seifteri A., The utility of «Google Trends» for epidemiological research: Lyme disease as an example, „Geospatial Health” 2010, nr 4(2), s. 135-37.

Skórka S., Nowe wyzwania architektury informacji, „Bibliotheca Nostra. Ślaski Kwartalnik Naukowy" 2016, nr 2(44), s. 10-22.

Smętkiewicz K., Latour T., Właściwości fizykochemiczne i chemiczne wód geotermalnych w Uniejowie ze szczególnym uwzględnieniem wody z odwiertu PIG/AGH-2, „Biuletyn Uniejowski” 2012, t. 1, s. 79-93.

Szromnik A., City placement - nowy element w strategii zintegrowanej komunikacji marketingowej miast, [w:] Marketing terytorialny, nowe obszary i narzędzia, red. A. Szromik, Wyd. edu-Libri, Kraków-Legionowo 2015, s. 101.

Ustawa z dnia 28 lipca 2005 r. o lecznictwie uzdrowiskowym, uzdrowiskach i obszarach ochrony uzdrowiskowej oraz o gminach uzdrowiskowych, Dz.U. 2017, poz. 1056.

Wiśniewski S., Significance of trans-european transport networks for logistics centre localization as exemplified by the Łódź region, „European Spatail Research and Policy” 2015, t. 22, nr 1, s. $23-44$.

Voseni S., Schmidt T., Forecasting Private Consumption: Survey-Based Indicators vs. Google Trends, „Journal of Forecasting” 2011, nr 30, s. 565-578. 
Załącznik 1. Popularność uzdrowisk nizinnych w Polsce w latach 2011-2017*

\begin{tabular}{|c|c|c|c|c|c|c|c|c|c|c|c|}
\hline \multirow[b]{2}{*}{$\begin{array}{l}\text { Miesiąc } \\
\text { i rok }\end{array}$} & \multicolumn{11}{|c|}{ Miasto o statusie uzdrowiska } \\
\hline & $\begin{array}{l}\frac{3}{0} \\
\frac{\pi}{0} \\
0 \\
0 \\
0 \\
\vdots\end{array}$ & $\begin{array}{l}: \overline{0} \\
\frac{0}{0} \\
N \\
0 \\
\frac{1}{0} \\
0 \\
0\end{array}$ & 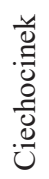 & 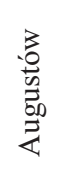 & $\frac{\text { त्ञ }}{\frac{\pi}{0}}$ & 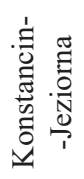 & 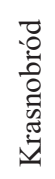 & 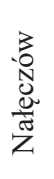 & 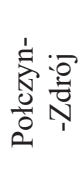 & 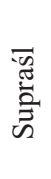 & 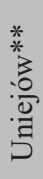 \\
\hline sty 11 & 80 & 41 & 23 & 27 & 19 & 15 & 4 & 13 & 6 & 3 & 9 \\
\hline lut 11 & 78 & 38 & 23 & 28 & 19 & 15 & 3 & 12 & 5 & 3 & 8 \\
\hline mar 11 & 82 & 39 & 22 & 29 & 17 & 16 & 3 & 13 & 5 & 3 & 6 \\
\hline kwi 11 & 82 & 37 & 23 & 30 & 17 & 17 & 5 & 14 & 5 & 4 & 8 \\
\hline maj 11 & 83 & 39 & 25 & 36 & 17 & 17 & 7 & 14 & 7 & 4 & 9 \\
\hline cze 11 & 89 & 38 & 27 & 45 & 19 & 19 & 7 & 15 & 9 & 5 & 13 \\
\hline lip 11 & 100 & 42 & 30 & 56 & 22 & 19 & 10 & 17 & 9 & 5 & 16 \\
\hline sie 11 & 91 & 40 & 31 & 50 & 21 & 19 & 11 & 18 & 7 & 5 & 18 \\
\hline wrz 11 & 88 & 38 & 25 & 32 & 18 & 21 & 4 & 13 & 6 & 5 & 9 \\
\hline paź 11 & 84 & 34 & 23 & 29 & 18 & 17 & 3 & 12 & 5 & 4 & 8 \\
\hline lis 11 & 76 & 35 & 21 & 28 & 16 & 17 & 3 & 14 & 4 & 3 & 9 \\
\hline gru 11 & 71 & 32 & 20 & 26 & 17 & 13 & 3 & 11 & 4 & 3 & 8 \\
\hline sty 12 & 80 & 38 & 23 & 29 & 21 & 16 & 3 & 12 & 6 & 5 & 8 \\
\hline lut 12 & 77 & 37 & 23 & 28 & 19 & 18 & 3 & 12 & 5 & 4 & 8 \\
\hline mar 12 & 81 & 35 & 24 & 29 & 17 & 19 & 3 & 12 & 5 & 4 & 6 \\
\hline kwi 12 & 85 & 36 & 26 & 34 & 18 & 16 & 4 & 14 & 5 & 5 & 10 \\
\hline maj 12 & 82 & 37 & 28 & 34 & 18 & 20 & 5 & 13 & 6 & 5 & 18 \\
\hline cze 12 & 81 & 37 & 26 & 40 & 18 & 19 & 7 & 14 & 6 & 6 & 25 \\
\hline lip 12 & 85 & 43 & 39 & 59 & 22 & 19 & 14 & 16 & 7 & 6 & 30 \\
\hline sie 12 & 85 & 40 & 35 & 53 & 20 & 20 & 9 & 18 & 6 & 6 & 41 \\
\hline wrz 12 & 85 & 38 & 27 & 31 & 17 & 20 & 5 & 13 & 5 & 4 & 21 \\
\hline paź 12 & 78 & 34 & 22 & 27 & 16 & 17 & 3 & 12 & 5 & 4 & 21 \\
\hline lis 12 & 73 & 32 & 21 & 27 & 17 & 16 & 2 & 11 & 4 & 3 & 20 \\
\hline gru 12 & 70 & 33 & 20 & 25 & 18 & 13 & 3 & 10 & 5 & 3 & 21 \\
\hline sty 13 & 77 & 37 & 22 & 27 & 20 & 15 & 3 & 11 & 5 & 4 & 27 \\
\hline lut 13 & 74 & 35 & 21 & 28 & 20 & 16 & 3 & 11 & 4 & 4 & 19 \\
\hline mar 13 & 73 & 33 & 20 & 27 & 17 & 16 & 3 & 10 & 4 & 4 & 14 \\
\hline kwi 13 & 83 & 37 & 26 & 33 & 18 & 19 & 4 & 13 & 5 & 4 & 16 \\
\hline maj 13 & 83 & 39 & 27 & 34 & 18 & 19 & 5 & 13 & 5 & 5 & 24 \\
\hline cze 13 & 82 & 39 & 29 & 40 & 19 & 20 & 6 & 14 & 5 & 6 & 26 \\
\hline
\end{tabular}


Popularność Uniejowa na tle małych miast regionu łódzkiego...

\begin{tabular}{|c|c|c|c|c|c|c|c|c|c|c|c|}
\hline \multirow[b]{2}{*}{$\begin{array}{c}\text { Miesiąc } \\
\text { i rok }\end{array}$} & \multicolumn{11}{|c|}{ Miasto o statusie uzdrowiska } \\
\hline & $\begin{array}{l}\frac{3}{0} \\
\frac{0}{0} \\
0 \\
\vdots \\
0 \\
0 \\
\vdots\end{array}$ & 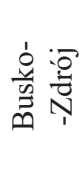 & 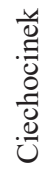 & 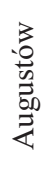 & 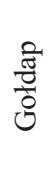 & 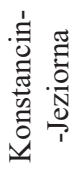 & 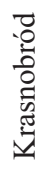 & 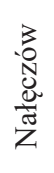 & 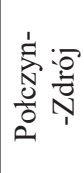 & 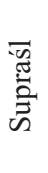 & 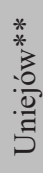 \\
\hline $\operatorname{lip} 13$ & 84 & 42 & 37 & 59 & 21 & 20 & 13 & 16 & 7 & 7 & 31 \\
\hline sie 13 & 82 & 43 & 36 & 53 & 20 & 19 & 10 & 17 & 6 & 8 & 51 \\
\hline wrz 13 & 76 & 40 & 27 & 33 & 16 & 18 & 5 & 12 & 6 & 5 & 16 \\
\hline paź 13 & 75 & 38 & 23 & 28 & 16 & 18 & 3 & 16 & 5 & 4 & 20 \\
\hline lis 13 & 72 & 36 & 22 & 26 & 15 & 17 & 3 & 14 & 4 & 3 & 19 \\
\hline gru 13 & 71 & 34 & 20 & 23 & 16 & 15 & 3 & 10 & 4 & 3 & 15 \\
\hline sty 14 & 80 & 40 & 23 & 27 & 21 & 16 & 3 & 12 & 4 & 4 & 25 \\
\hline lut 14 & 74 & 40 & 24 & 27 & 20 & 15 & 3 & 14 & 5 & 4 & 30 \\
\hline mar 14 & 76 & 35 & 24 & 27 & 19 & 18 & 3 & 15 & 5 & 4 & 15 \\
\hline kwi 14 & 78 & 38 & 25 & 30 & 18 & 18 & 5 & 15 & 5 & 5 & 16 \\
\hline maj 14 & 78 & 39 & 28 & 34 & 19 & 20 & 6 & 13 & 5 & 6 & 34 \\
\hline cze 14 & 82 & 41 & 31 & 44 & 22 & 19 & 8 & 15 & 6 & 6 & 30 \\
\hline lip 14 & 82 & 46 & 37 & 64 & 23 & 20 & 16 & 16 & 7 & 7 & 39 \\
\hline sie 14 & 85 & 46 & 39 & 50 & 24 & 21 & 10 & 19 & 7 & 6 & 50 \\
\hline wrz 14 & 81 & 46 & 25 & 31 & 19 & 20 & 4 & 13 & 5 & 5 & 18 \\
\hline paź 14 & 78 & 43 & 25 & 27 & 20 & 18 & 3 & 12 & 5 & 4 & 17 \\
\hline lis 14 & 77 & 41 & 24 & 30 & 23 & 18 & 3 & 12 & 5 & 4 & 20 \\
\hline gru 14 & 71 & 37 & 20 & 25 & 21 & 16 & 3 & 11 & 5 & 4 & 17 \\
\hline sty 15 & 80 & 41 & 23 & 26 & 24 & 16 & 4 & 13 & 4 & 4 & 22 \\
\hline lut 15 & 80 & 41 & 25 & 28 & 21 & 18 & 3 & 13 & 5 & 4 & 21 \\
\hline $\operatorname{mar} 15$ & 75 & 39 & 24 & 29 & 20 & 17 & 3 & 13 & 4 & 4 & 15 \\
\hline kwi 15 & 82 & 37 & 27 & 31 & 21 & 18 & 4 & 15 & 5 & 4 & 16 \\
\hline maj 15 & 80 & 38 & 29 & 33 & 20 & 19 & 5 & 16 & 6 & 7 & 23 \\
\hline cze 15 & 86 & 42 & 31 & 43 & 22 & 20 & 8 & 15 & 6 & 7 & 25 \\
\hline $\operatorname{lip} 15$ & 87 & 43 & 43 & 67 & 28 & 20 & 15 & 17 & 7 & 7 & 34 \\
\hline sie 15 & 84 & 46 & 39 & 58 & 27 & 21 & 12 & 20 & 7 & 7 & 50 \\
\hline wrz 15 & 81 & 43 & 29 & 32 & 22 & 21 & 4 & 13 & 5 & 5 & 18 \\
\hline paź 15 & 79 & 40 & 22 & 29 & 20 & 18 & 3 & 12 & 4 & 4 & 16 \\
\hline lis 15 & 72 & 35 & 21 & 26 & 19 & 17 & 3 & 11 & 4 & 4 & 16 \\
\hline gru 15 & 71 & 37 & 21 & 23 & 23 & 16 & 2 & 11 & 5 & 4 & 17 \\
\hline sty 16 & 76 & 42 & 24 & 28 & 24 & 17 & 3 & 13 & 4 & 4 & 20 \\
\hline lut 16 & 78 & 43 & 25 & 30 & 24 & 18 & 4 & 14 & 5 & 5 & 19 \\
\hline
\end{tabular}


Załącznik 1. (cd.)

\begin{tabular}{|c|c|c|c|c|c|c|c|c|c|c|c|}
\hline \multirow[b]{2}{*}{$\begin{array}{l}\text { Miesiąc } \\
\text { i rok }\end{array}$} & \multicolumn{11}{|c|}{ Miasto o statusie uzdrowiska } \\
\hline & $\begin{array}{l}3 \\
\frac{3}{0} \\
0 \\
0 \\
0 \\
0 \\
\vdots\end{array}$ & 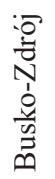 & 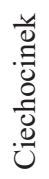 & 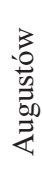 & $\frac{\frac{\pi}{0}}{\frac{0}{0}}$ & 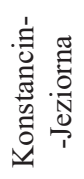 & 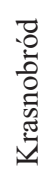 & $\frac{3}{3}$ & 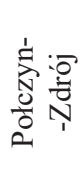 & 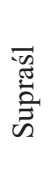 & 草 \\
\hline $\operatorname{mar} 16$ & 76 & 39 & 22 & 28 & 21 & 16 & 3 & 12 & 4 & 4 & 13 \\
\hline kwi 16 & 79 & 42 & 29 & 33 & 20 & 18 & 5 & 14 & 5 & 5 & 15 \\
\hline maj 16 & 83 & 43 & 34 & 35 & 24 & 22 & 6 & 14 & 5 & 6 & 18 \\
\hline cze 16 & 82 & 44 & 30 & 45 & 25 & 21 & 8 & 14 & 6 & 7 & 20 \\
\hline $\operatorname{lip} 16$ & 85 & 47 & 42 & 71 & 25 & 20 & 14 & 17 & 7 & 7 & 50 \\
\hline sie 16 & 85 & 48 & 39 & 62 & 24 & 20 & 12 & 19 & 6 & 7 & 67 \\
\hline wrz 16 & 87 & 43 & 31 & 36 & 20 & 23 & 5 & 14 & 5 & 5 & 23 \\
\hline paź 16 & 76 & 41 & 26 & 28 & 17 & 19 & 3 & 12 & 4 & 4 & 17 \\
\hline lis 16 & 78 & 37 & 23 & 27 & 16 & 18 & 3 & 11 & 4 & 3 & 14 \\
\hline gru 16 & 74 & 39 & 19 & 26 & 16 & 16 & 3 & 10 & 4 & 4 & 13 \\
\hline sty 17 & 80 & 43 & 25 & 31 & 21 & 18 & 3 & 12 & 5 & 4 & 19 \\
\hline lut 17 & 82 & 43 & 28 & 30 & 19 & 17 & 3 & 13 & 6 & 5 & 19 \\
\hline mar 17 & 79 & 40 & 27 & 29 & 16 & 19 & 3 & 12 & 5 & 5 & 14 \\
\hline kwi 17 & 83 & 42 & 29 & 33 & 17 & 20 & 5 & 14 & 6 & 5 & 16 \\
\hline maj 17 & 85 & 43 & 34 & 39 & 17 & 22 & 6 & 14 & 6 & 6 & 16 \\
\hline cze 17 & 95 & 48 & 36 & 53 & 20 & 24 & 9 & 16 & 7 & 7 & 30 \\
\hline lip 17 & 96 & 51 & 46 & 75 & 22 & 21 & 15 & 18 & 7 & 9 & 47 \\
\hline sie 17 & 94 & 55 & 43 & 65 & 21 & 21 & 12 & 21 & 7 & 8 & 34 \\
\hline wrz 17 & 89 & 46 & 30 & 36 & 15 & 22 & 4 & 13 & 6 & 5 & 17 \\
\hline paź 17 & 87 & 43 & 26 & 30 & 15 & 21 & 3 & 13 & 5 & 4 & 16 \\
\hline lis 17 & 80 & 41 & 26 & 28 & 16 & 20 & 3 & 11 & 5 & 3 & 16 \\
\hline gru 17 & 76 & 41 & 21 & 29 & 16 & 17 & 3 & 11 & 4 & 4 & 15 \\
\hline
\end{tabular}

* Z uwagi na obszerność informacji przedstawionych w tabeli nie przedstawiono w niej danych z 2010 r. ** Miasto formalnie uzyskało status uzdrowiska w czerwcu 2012 r.

Źródło: opracowanie własne na podstawie Google Trends 


\title{
POPULARITY OF UNIEJÓW AGAINST OTHER SMALL TOWNS AND SPA RESORTS IN ŁÓDŹ REGION
}

\begin{abstract}
Summary
The article examines the popularity of Uniejów and other small towns and spa resorts with a similar profile within the boundaries of the voivodeship of Łódź. The popularity was measured by the number of searches for each of these towns via the Google search engine. In addition, an analysis was made of season-connected changes in looking up Uniejów on the Internet, and the results were compared with promotional actions implemented by the Municipal Office. The findings indicate that Uniejów is the best known settlement in the group of small towns of Łódź region and, considering its potential and length of functioning, a major spa resort.
\end{abstract}

Keywords: Google trends, spa resort, Uniejów

Data wplywu artykułu: maj 2019

Data akceptacji: czerwiec 2019 